\title{
Predictors of red blood cell transfusion after cardiac surgery: a prospective cohort study*
}

\author{
Fatores preditores de transfusão de concentrado de hemácias \\ após cirurgia cardíaca: um estudo coorte prospectivo \\ Factores predictivos de transfusión de concentrado de hematíes \\ después de cirugía cardiaca: un estudio cohorte prospectivo
}

Camila Takao Lopes ${ }^{1,2}$, Evelise Helena Fadini Reis Brunori ${ }^{3}$, Agueda Maria Ruiz Zimmer Cavalcante ${ }^{1}$, Sue Ann Moorhead ${ }^{4}$, Juliana de Lima Lopes ${ }^{1}$, Alba Lucia Bottura Leite de Barros ${ }^{1}$

\footnotetext{
* Extracted from the thesis "Incidência de sangramento excessivo e preditores no pósoperatório imediato de cirurgia cardíaca”, Escola Paulista de Enfermagem, Universidade Federal de São Paulo, 2015.

${ }^{1}$ Universidade Federal de São Paulo, Escola Paulista de Enfermagem, São Paulo, SP, Brazil.

${ }^{2}$ Universidade de São Paulo, Hospital Universitário, São Paulo, SP, Brazil

${ }^{3}$ Instituto Dante Pazzanese de Cardiologia, São Paulo, SP, Brazil.

${ }^{4}$ University of Iowa, College of Nursing, Iowa City, IA, United States of America.
}

\begin{abstract}
Objective: To identify predictors of red blood cell transfusion (RBCT) after cardiac surgery. Method: A prospective cohort study performed with 323 adults after cardiac surgery, from April to December of 2013. A data collection instrument was constructed by the researchers containing factors associated with excessive bleeding after cardiac surgery, as found in the literature, for investigation in the immediate postoperative period. The relationship between risk factors and the outcome was assessed by univariate analysis and logistic regression. Results: The factors associated with RBCT in the immediate postoperative period included lower height and weight, decreased platelet count, lower hemoglobin level, higher prevalence of platelet count $<150 \times 10^{3} / \mathrm{mm}^{3}$, lower volume of protamine, longer duration of anesthesia, higher prevalence of intraoperative RBCT, lower body temperature, higher heart rate and higher positive end-expiratory pressure. The independent predictor was weight $<66.5 \mathrm{Kg}$. Conclusion: Factors associated with RBCT in the immediate postoperative period of cardiac surgery were found. The independent predictor was weight.
\end{abstract}

\section{DESCRIPTORS}

Thoracic Surgery; Hemorrhage; Blood Transfusion; Erythrocyte Transfusion; Cardiovascular Nursing. 


\section{INTRODUCTION}

Red blood cell (RBC) transfusion is a frequent requirement after cardiac surgery, with $20.4 \%-48 \%$ occurring in the immediate postoperative period ${ }^{(1-4)}$. Although it is lifesaving after cardiac surgery, RBC transfusion increases death rates from $5.4 \%$ to $13.4 \%$ in the long term, whereas median time to death is decreased from 4.7 years to 1.1 years $^{(3)}$. Even among low-risk patients undergoing simple cardiac surgery, perioperative RBC transfusion is significantly associated with mortality after more than 4500 days $^{(5)}$. In the short term, RBC transfusion $\geq 4$ units is an independent predictor of one-year mortality ${ }^{(2)}$. The risk for cardiac morbidity, different types of infections, acute respiratory distress syndrome and acute renal injury requiring dialysis or hemofiltration is also increased after RBC transfusion ${ }^{(1,4,6)}$.

Given the increased morbidity and mortality associated with $\mathrm{RBC}$ transfusion, attempts to decrease allogeneic blood consumption during cardiac surgeries have been made through alternative treatment options. A nontransfusional approach during pre-, intra-, and post-operative care has been recently proposed, including optimizing the erythrocyte mass and coagulation status, minimizing blood loss, and tolerating anemia ${ }^{(7)}$.

However, the prevalence of $\mathrm{RBC}$ transfusion is widely variable in different institutions due to different patient characteristics, surgical procedures, comorbidities and institutional transfusion practices. Therefore, in order to decrease blood consumption, each institution should regularly evaluate transfusion requirements in cardiac surgery to identify high-risk patients ${ }^{(8)}$.

Because the RBC transfusion requirement is a complication arising from excessive bleeding, an integrative literature review was conducted by the authors of the present study to investigate the predictive factors for excessive bleeding after cardiac surgery, using the databases of CINAHL, Cochrane, Lilacs, Medline, Science Direct, Scopus, and JBI COnNECT+. The review found 1528 articles, out of which 17 good-quality studies published from 2004 to 2014 were included (in press). As expected, a great variety of factors were found (Chart 1$)^{(9)}$.

Given the existence of multiple possible risk factors for $\mathrm{RBC}$, a question arises regarding the context of the institution where this study was developed: what are the predictive factors for RBC transfusion after cardiac surgery? Knowledge of the institutional risk factors should aid nurses in prioritizing vigilance for complications considering high-risk patients, since these professionals must perform multiple and simultaneous activities upon patient admission to the ICU after cardiac surgeries ${ }^{(10-11)}$. In addition to prioritizing vigilance, implementation of strategies to minimize blood transfusion relies on nursing actions that require knowledge of institutional risk factors; these should not be routinely performed as mechanical activities.

The objective of this study was to identify predictive factors for RBC transfusion after cardiac surgery.

\section{METHOD}

This is a prospective cohort study conducted at a tertiary university hospital, which is specialized in cardiac care in São Paulo, SP, Brazil. It is part of a larger study investigating the predictive factors for excessive bleeding (in press) and bleeding-related re-exploration ${ }^{(12)}$ after cardiac surgery. The sample consisted of adult patients $(\geq 18$ years old) requiring surgical correction of acquired cardiac diseases, through median sternotomy. The surgeries included: coronary artery bypass grafting $(\mathrm{CABG})$, valve replacement or repair, correction of aorta aneurism/dissection, heart transplantation, mixoma excision or combined surgery, which was any procedure other than isolated ones. The exclusion criterion was patients whose charts did not contain all the variables studied.

The sample size was calculated to estimate differences between patients with and without RBC transfusion, with a $95 \%$ significance level and $80 \%$ power ${ }^{(13)}$. Initially, three different sample sizes were calculated for one-tailed tests of hypotheses, on the basis of the mean values of age, preoperative hemoglobin ( $\mathrm{Hb}$ ) levels, and cardiopulmonary bypass $(\mathrm{CPB})$ time and their respective standard deviations as found by a previous study comparing patients with and without $\mathrm{RBC}$ transfusion ${ }^{(14)}$. These variables were chosen because they are high risk factors for bleeding and RBC transfusion after cardiac surgery ${ }^{(14-15)}$. The mean values and standard deviations considered for age, $\mathrm{Hb}$ levels and $\mathrm{CPB}$ time in patients with and without $\mathrm{RBC}$ transfusion were, respectively: $70 \pm 10$ vs. $66 \pm 9$ years old, $13.6 \pm 1.4$ vs. $14.1 \pm 1.4$ $\mathrm{mg} / \mathrm{dL}$ and $82 \pm 26$ vs. $71 \pm 23$ minutes $^{(16)}$. Considering the one-tailed test of hypotheses (Null hypothesis $=$ mean for the group with $\mathrm{RBC}$ transfusion $\leq$ mean for the group without RBC transfusion; alternative hypothesis: mean for the group with RBC transfusion > mean for the group without $\mathrm{RBC}$ transfusion), the size of each group is calculated by:

$$
\mathrm{n}=\frac{\left(Z_{\alpha}+Z_{\beta}\right)^{2} \sigma^{2}}{\epsilon^{2}}
$$

Where:

$\alpha$ is the significance level

$\beta$ is the power

$\sigma$ is the standard deviation

$\epsilon$ is the mean difference between the two groups.

The largest sample size obtained was 194, of which at least 97 should have the primary outcome of the larger study, excessive bleeding.

The outcome that was investigated in the study, was any $R B C$ transfusion (yes or no) required within the first 24 postoperative hours, was selected because patient severity and the incidence of bleeding complications are higher during this period ${ }^{(4,16)}$. Data regarding outcome occurrence were collected 24 hours after admission to the intensive care unit (ICU). Postoperative RBC transfusion was performed in order to maintain the hematocrit (Hct) above $28 \%$.

The selection of factors potentially associated with $\mathrm{RBC}$ transfusion was based on the integrative review, as 
mentioned in the introduction section (Chart 1), ${ }^{(9)}$ and the Society of Thoracic Surgeons and Society of Cardiovascular Anesthesiologists Clinical Practice Guideline ${ }^{(15)}$. A data collection instrument was constructed by the authors containing these factors and the outcomes to be evaluated. In addition, the authors also developed specific instructions for data collection in written form (e.g. Hemoglobin (g/dL): values found in the last preoperative exam as stated in the electronic system; Volume expansion ( $\mathrm{mL}$ ): amount of IV fluid received during surgery as stated on the surgical form).

Chart 1 - Factors possibly associated with red blood cell transfusion after cardiac surgery - São Paulo, SP, Brazil, 2004-2014 ${ }^{(9)}$.

\begin{tabular}{|c|}
\hline Patient-related factors and preoperative conditions \\
\hline $\begin{array}{l}\text { Gender (male or female); age (years); weight }(\mathrm{Kg}) ; \text { height }(\mathrm{m}) ; \\
\text { body mass index }\left(\mathrm{Kg} / \mathrm{m}^{2}\right) ; \text { previous bleeding history (yes or no); } \\
\text { hemoglobin }(\mathrm{g} / \mathrm{dL}) ; \text { hematocrit }(\%) ; \text { platelet count }\left(\mathrm{x} 10^{3} / \mathrm{mm}^{3}\right) ; \\
\text { platelet count }<150 \times 10^{3} / \mathrm{mm}^{3}(\text { yes or no); prothrombin time } \\
\text { international normalized ratio (INR); activated prothrombin time } \\
\text { ratio; fibrinogen (mg/dL); preoperative use of antithrombotic } \\
\text { therapy (aspirin, coumarin-type anticoagulants or platelet ADP- } \\
\text { receptor blocker; yes or no); preoperative use of non-steroidal } \\
\text { anti-inflammatories (yes or no); heart failure (yes or no); New York } \\
\text { Heart Association functional class (II, III or IV); left ventricular } \\
\text { ejection fraction (\%); preoperative cardiogenic shock (yes or no); } \\
\text { preoperative kidney failure or need for hemodialysis (yes or no); } \\
\text { type I diabetes mellitus (yes or no); preoperative sepsis (yes or no); } \\
\text { chronic obstructive pulmonary disease (yes or no); liver failure } \\
\text { (yes or no); peripheral vascular disease (yes or no); need for } \\
\text { preoperative blood product transfusion (yes or no). }\end{array}$ \\
\hline Surgery-related factors \\
\hline $\begin{array}{l}\text { Urgency of surgery (elective, urgent, emergency); type of surgery } \\
\text { (CABG, valve, aorta, heart transplantation, mixoma excision, } \\
\text { combined surgery); surgical team (coded through letters A to M); } \\
\text { bypasses (number of); type of valve (biological or mechanical); } \\
\text { use of cardiopulmonary bypass (CPB); CPB time (min); aorta } \\
\text { clamp time (min); initial and final activated clotting times (min); } \\
\text { sternal wires (number of); chest tubes (number of); heparin } \\
\text { volume (mL); protamine volume (mL); duration of anesthesia } \\
\text { (min); volume expansion (mL); use of } \varepsilon \text {-aminocaproic acid (yes } \\
\text { or no); use of cell saver (yes or no); use of autologous transfusion } \\
\text { (yes or no); need for intraoperative blood product transfusion - } \\
\text { RBC, fresh frozen plasma (FFP), cryoprecipitate and/or platelet } \\
\text { (yes or no). }\end{array}$ \\
\hline Postoperative factors \\
\hline $\begin{array}{l}\text { Low body temperature }\left({ }^{\circ} \mathrm{C} \text {; the lowest value); High mean arterial }\right. \\
\text { pressure (mmHg; the highest value), High heart rate (bpm; the } \\
\text { highest value), High positive end expiratory pressure }\left(\mathrm{cmH}_{2} \mathrm{O} \text {; the }\right. \\
\text { highest value), metabolic acidosis (yes or no) during the } 24 \text { hours } \\
\text { following the surgery }\end{array}$ \\
\hline
\end{tabular}

The main researcher recruited the patients preoperatively from April to December of 2013, explained the objectives of the study, and facilitated signing of the Terms of Free and Informed consent form, guaranteeing anonymity and confidentiality. Two nurse investigators with research and clinical experience independently collected data on the possible risk factors and the outcome from the patients' charts.

The nurses pilot tested the data collection procedures with ten charts to ensure similar collection methods. When comparing these data collected by the two nurses, no differences were found; therefore, these patients were included in the sample. The patient-related factors were investigated within 24 hours before surgery. The surgical factors were investigated immediately after arrival to the ICU and the postoperative factors were investigated 24 hours after admission to the ICU. The Ethics Committees of both the
Hospital (Protocol n. 597.096-0/2013) and the University (Protocol n. 215.144/2013) approved the study.

Data were entered into SPSS software (SPSS v.19, SPSS Inc., Chicago, IL, USA) spreadsheets. Quantitative variables are presented as means \pm standard deviation (SD). Categorical variables are shown as absolute frequencies and percentages. Data normality was tested using the Shapiro-Wilk test before further analysis was conducted. Univariate analysis was performed using Fisher's exact test for categorical variables and the Mann-Whitney test for continuous variables. Variables with $\mathrm{p} \leq 0.05$ in the univariate analysis and clinically relevant variables were included in a multivariable logistic regression. We adopted a 5\% level of significance to decide on the inclusion of the variables in the multivariable analysis, instead of the usual 20\% significance level, with the goal of increasing rigor when assessing which variables would remain significant in the presence of other significant and clinically important variables.

The accuracy of the relationship between the outcome and independent variables was depicted through the area under the receiver-operating characteristic (ROC) curve, with the cut-off points with the highest sensitivity and specificity. The cut-off points of greater sensitivity and specificity in the ROC curve for quantitative variables significantly associated with the outcomes were also identified.

\section{RESULTS}

The final sample consisted of 323 patients ( 350 prospectively recruited until at least 97 presented with excessive bleeding, six refused to sign the consent form, and $21 \mathrm{had}$ incomplete charts). The patients were mostly male (64.0\%), with a mean age of $60.2 \pm 13.1$ years undergoing CABG (48.9\%), valve repair or replacement $(36.8 \%)$, combined surgery $(8.4 \%)$, aortic correction $(4.0 \%)$, heart transplantation $(1.6 \%)$ or mixoma excision $(0.3 \%)$.

Twenty patients $(6.2 \%)$ required postoperative transfusion of one $(n=14 ; 70 \%)$, two $(n=5 ; 25 \%)$ or three $(n=1 ; 5 \%)$ RBC units. Out of these, 17 (85\%) were also administered $2-6 \mathrm{~mL}$ of protamine supplementation and 19 (95\%) received $\varepsilon$-aminocaproic acid postoperatively. Sixteen (80\%) were transfused with $1-5$ units of fresh frozen plasma (FFP), eight (40\%) with $6-8$ units of platelets, and two (10\%) with $1-7$ units of cryoprecipitate within the 24 hours after surgery.

Patient factors significantly associated with postoperative RBC transfusion included: older age; lower weight and height - but not lower BMI; lower preoperative platelet count (although within the limits of normality); lower preoperative hemoglobin levels; and greater prevalence of preoperative platelet count $<150 \times 10^{3} / \mathrm{mm}^{3}$ (Table 1). Surgical factors significantly associated with postoperative RBC transfusion were a lower volume of protamine; longer duration of anesthesia; and a greater incidence of intraoperative $\mathrm{RBC}$ transfusion (Table 2). Postoperative characteristics significantly associated with postoperative RBC transfusion were a lower body temperature; higher heart rate; and higher positive end expiratory pressure during mechanical ventilation (Table 3 ). 
Table 1 - Patient-related factors associated with red blood cell transfusion in adult patients undergoing open-chest cardiac surgery São Paulo, SP, Brazil, 2013.

\begin{tabular}{|c|c|c|c|}
\hline Variable & $R B C$ transfusion $(n=20)$ & No $R B C$ transfusion $(n=303)$ & p-value \\
\hline Age (years) & $67.35 \pm 9.08$ & $59.75 \pm 13.23$ & 0.012 \\
\hline \multicolumn{4}{|l|}{ Gender } \\
\hline Male & $12(60.0)$ & $194(64.0)$ & 0.811 \\
\hline Female & $8(40.0)$ & $109(36)$ & \\
\hline Weight (Kg) & $65.65 \pm 11.64$ & $73.94 \pm 14.83$ & 0.014 \\
\hline Height (m) & $1.60 \pm 0.10$ & $1.65 \pm 0.09$ & 0.025 \\
\hline Body mass index $\left(\mathrm{Kg} / \mathrm{m}^{2}\right)$ & $25.81 \pm 4.98$ & $27.07 \pm 4.66$ & 0.151 \\
\hline Preoperative platelet count $\left(\times 10^{3} / \mathrm{mm}^{3}\right)$ & $177.95 \pm 78.63$ & $232.86 \pm 744.20$ & $<0.001$ \\
\hline $\begin{array}{l}\text { Preoperative platelet count }<150 \times 10^{3} / \\
\mathrm{mm}^{3}\end{array}$ & $7(35.0)$ & $22(7.3)$ & 0.001 \\
\hline Preoperative hemoglobin $(\mathrm{g} / \mathrm{dL})$ & $12.97 \pm 2.04$ & $13.71 \pm 1.79$ & 0.047 \\
\hline Preoperative hematocrit (\%) & $39.79 \pm 6.20$ & $41.44 \pm 5.18$ & 0.109 \\
\hline $\begin{array}{l}\text { International normalized prothrombin } \\
\text { time ratio }\end{array}$ & $1.14 \pm 0.20$ & $1.11 \pm 0.15$ & 0.745 \\
\hline $\begin{array}{l}\text { Activated partial thromboplastin time } \\
\text { ratio }\end{array}$ & $1.07 \pm 3.90$ & $1.09 \pm 0.28$ & 0.798 \\
\hline Preoperative fibrinogen levels (mg/dL) & $298.22 \pm 64.16$ & $329.19 \pm 87.35$ & 0.158 \\
\hline Left ventricle ejection fraction (\%) & $54.61 \pm 15.97$ & $57.39 \pm 11.53$ & 0.894 \\
\hline Use of aspirin & $15(88.2)$ & $190(84.1)$ & 1.000 \\
\hline Use of warfarin & $1(5.9)$ & $15(6.6)$ & 1.000 \\
\hline Use of clopidogrel & 0 & $34(14.9)$ & 0.140 \\
\hline Cardiogenic shock & 0 & $6(2.0)$ & 1.000 \\
\hline Kidney failure & $1(5.0)$ & $13(4.3)$ & 0.603 \\
\hline Heart failure & $12(63.2)$ & $182(63.2)$ & 1.000 \\
\hline $\begin{array}{l}\text { New York Heart Association functional } \\
\text { class }\end{array}$ & & & 0.355 \\
\hline II & $5(27.8)$ & $115(41.2)$ & \\
\hline III & $6(33.3)$ & $50(17.9)$ & \\
\hline IV & 0 & $8(2.9)$ & \\
\hline Hypertension & $17(85)$ & $234(77.2)$ & 0.582 \\
\hline Type I diabetes & 0 & $5(1.7)$ & 1.000 \\
\hline Chronic obstructive pulmonary disease & 0 & $20(6.6)$ & 0.623 \\
\hline Peripheral vascular disease & $2(10)$ & $17(5.6)$ & 0.332 \\
\hline
\end{tabular}

Quantitative variables presented as mean $\pm \mathrm{SD}$ and categorical variables presented as absolute frequency (percentages). 
Table 2 - Surgical factors associated with red blood cell transfusion in adult patients undergoing open-chest cardiac surgery - São Paulo, SP, Brazil, 2013.

\begin{tabular}{|c|c|c|c|}
\hline Variables & RBC transfusion $(n=20)$ & No RBC transfusion $(n=303)$ & p-value \\
\hline \multicolumn{4}{|l|}{ Type of surgery } \\
\hline Coronary artery bypass grafting & $10(50.0)$ & $148(48.9)$ & \multirow[t]{6}{*}{0.983} \\
\hline Valve & $8(40.0)$ & $111(36.6)$ & \\
\hline Combined & $2(10.0)$ & $25(8.3)$ & \\
\hline Aorta & 0 & $13(4.0)$ & \\
\hline Heart transplantation & 0 & $5(1.7)$ & \\
\hline Mixoma excision & 0 & $1(0.3)$ & \\
\hline \multicolumn{4}{|l|}{ Surgical urgency } \\
\hline Elective & $20(100.0)$ & 299 (99.3) & \multirow[t]{2}{*}{1.000} \\
\hline Emergency & 0 & $2(0.7)$ & \\
\hline \multicolumn{4}{|l|}{ Type of valve } \\
\hline Biological & $7(77.7)$ & $84(74.3)$ & \multirow[t]{3}{*}{1.000} \\
\hline Mechanical & $2(22.2)$ & $29(25.3)$ & \\
\hline Use of cardiopulmonary bypass time & $20(100.0)$ & $301(99.3)$ & \\
\hline Cardiopulmonary bypass time (min) & $105.60 \pm 41.47$ & $100.97 \pm 43.77$ & 0.439 \\
\hline Aorta clamp time (min) & $73.55 \pm 33.56$ & $71.00 \pm 35.40$ & 0.582 \\
\hline Initial activated clotting time (min) & $162.25 \pm 29.28$ & $158.67 \pm 35.33$ & 0.407 \\
\hline Final activated clotting time (min) & $151.65 \pm 23.70$ & $154.66 \pm 32.50$ & 0.802 \\
\hline Sternal wires (n) & $5.74 \pm 1.05$ & $5.89 \pm 0.88$ & 0.298 \\
\hline Bypasses (n) & $2.42 \pm 0.90$ & $2.66 \pm 0.82$ & 0.356 \\
\hline Chest tubes (n) & $1.95 \pm 0.69$ & $1.81 \pm 0.69$ & 0.354 \\
\hline Heparin (mL) & $6.25 \pm 2.45$ & $6.30 \pm 1.31$ & 0.197 \\
\hline Protamine (mL) & $23.10 \pm 5.64$ & $25.81 \pm 5.39$ & 0.015 \\
\hline Duration of anesthesia (min) & $369.75 \pm 66.14$ & $338.78 \pm 75.20$ & 0.032 \\
\hline Fluid volume (mL) & $2700.00 \pm 909.02$ & $2894.78 \pm 831.10$ & 0.462 \\
\hline Use of $\varepsilon$-aminocaproic acid & $9(45.0)$ & $146(48.2)$ & 0.821 \\
\hline Use of cell saver & 0 & $8(2.6)$ & 1.000 \\
\hline Use of autologous transfusion & $1(5.0)$ & $63(20.8)$ & 0.142 \\
\hline \multicolumn{4}{|l|}{ Surgical team } \\
\hline A & $2(10.0)$ & $38(12.5)$ & \multirow{13}{*}{0.951} \\
\hline $\mathrm{B}$ & $4(20.0)$ & $56(18.5)$ & \\
\hline $\mathrm{C}$ & $4(20.0)$ & $37(12.2)$ & \\
\hline $\mathrm{D}$ & 0 & $9(3.0)$ & \\
\hline E & $4(20.0)$ & $40(13.2)$ & \\
\hline $\mathrm{F}$ & 0 & $3(1.0)$ & \\
\hline G & $2(10.0)$ & $19(6.3)$ & \\
\hline $\mathrm{H}$ & $1(5.0)$ & $22(7.3)$ & \\
\hline I & $1(5.0)$ & $33(10.9)$ & \\
\hline$J$ & 0 & $5(1.7)$ & \\
\hline K & 0 & $19(6.3)$ & \\
\hline L & $2(10.0)$ & $21(6.9)$ & \\
\hline M & 0 & $1(0.3)$ & \\
\hline \multicolumn{4}{|l|}{ Intraoperative transfusion } \\
\hline Red blood cell & $8(40)$ & $63(20.8)$ & 0.054 \\
\hline Fresh frozen plasma & $3(15)$ & $32(10.6)$ & 0.465 \\
\hline Cryoprecipitate & $1(5)$ & $20(6.6)$ & 1.000 \\
\hline Platelet & $3(15)$ & $16(5.3)$ & 0.104 \\
\hline
\end{tabular}


Table 3 - Postoperative factors associated with red blood cell transfusion or bleeding-related re-exploration in adult patients undergoing open-chest cardiac surgery-São Paulo, SP, Brazil, 2013.

\begin{tabular}{|c|c|c|c|}
\hline Variables & $\begin{array}{c}\mathbf{R B C} \\
\text { transfusion } \\
(\mathbf{n}=\mathbf{2 0})\end{array}$ & $\begin{array}{c}\text { No RBC } \\
\text { transfusion } \\
(n=303)\end{array}$ & p-value \\
\hline $\begin{array}{l}\text { Lowest temperature } \\
\qquad\left({ }^{\circ} \mathrm{C}\right)\end{array}$ & $34.59 \pm 1.09$ & $35.14 \pm 0.73$ & 0.025 \\
\hline Highest MAP (mmHg) & $98.45 \pm 18.85$ & $100.52 \pm 14.18$ & 0.765 \\
\hline $\begin{array}{l}\text { Highest heart rate } \\
\text { (bpm) }\end{array}$ & $116.70 \pm 20.22$ & $104.49 \pm 17.94$ & 0.012 \\
\hline $\begin{array}{l}\text { Highest respiratory } \\
\text { rate (rpm) }\end{array}$ & $22.05 \pm 4.71$ & $21.55 \pm 3.15$ & 0.853 \\
\hline IV volume (mL) & $\begin{array}{l}1457.89 \pm \\
882.12\end{array}$ & $\begin{array}{l}1279.06 \pm \\
686.12\end{array}$ & 0.415 \\
\hline Highest PEEP $\left(\mathrm{cmH}_{2} \mathrm{O}\right)$ & $6.35 \pm 3.01$ & $5.37 \pm 1.06$ & 0.016 \\
\hline Metabolic acidosis & $11(55.0)$ & $144(47.5)$ & 0.645 \\
\hline
\end{tabular}

Quantitative variables presented as mean $\pm \mathrm{SD}$ and categorical variables presented as absolute frequency (percentages). IV: Intravenous; MAP: Mean arterial pressure PEEP: Positive end-expiratory pressure; RBCT: Red blood cell transfusion.

On multivariable analysis, the independent predictor of postoperative RBC transfusion was weight (Table 4), the cut-off point in the ROC curves was 66.5. Therefore, weighing less than 66.5 will increase the chance for postoperative $\mathrm{RBC}$ transfusion. This result predicts the relationship between the independent variables and the outcome with a sensitivity of $65.0 \%$ [ $95 \%$ CI: $0.409-0.837$, a specificity of $68.0 \%$ [95\% CI: $0.624-0.731$ ], an area under the curve of $66.0 \%$ [95\% CI: $55.0-77.8]$ and an accuracy of $67.8 \%$ [95\% CI: $62.4-72.8]$.

Table 4 - Multivariable logistic regression analysis of predictive factors for red blood cell transfusion in adult patients undergoing open-chest cardiac surgery - São Paulo, SP, Brazil, 2013.

\begin{tabular}{lccc}
\hline Variables & p-value & $\begin{array}{c}\text { Odds } \\
\text { ratio }\end{array}$ & $\begin{array}{c}\text { 95\% confidence } \\
\text { interval }\end{array}$ \\
\hline Age (years) & 0.091 & 1.04 & $0.99-1.10$ \\
Height $(\mathrm{m})$ & 0.613 & 0.14 & $0.00-309.29$ \\
$\begin{array}{l}\text { Weight }(\mathrm{Kg}) \\
\begin{array}{l}\text { Preoperative hemoglobin } \\
\text { (g/dL) }\end{array}\end{array}$ & 0.046 & 0.94 & $0.89-1.00$ \\
$\begin{array}{l}\text { Preoperative platelet count } \\
\left.\text { (x10 }{ }^{3} / \mathrm{mm}^{3}\right)\end{array}$ & 0.304 & 1.00 & $0.99-1.00$ \\
$\begin{array}{l}\text { Preoperative fibrinogen } \\
\text { levels (mg/dL) }\end{array}$ & 0.402 & 1.00 & $0.99-1.00$ \\
$\begin{array}{l}\text { Duration of anesthesia } \\
\text { (min) }\end{array}$ & 0.291 & 1.00 & $1.00-1.01$ \\
$\begin{array}{l}\text { Lowest postoperative } \\
\text { temperature }\left({ }^{\circ} \mathrm{C}\right)\end{array}$ & 0.829 & 0.92 & $0.45-1.90$ \\
$\begin{array}{l}\text { Highest postoperative heart } \\
\text { rate }(\text { bpm) }\end{array}$ & 0.073 & 1.03 & $1.00-1.06$ \\
$\begin{array}{l}\text { Highest postoperative } \\
\text { positive end expiratory } \\
\text { pressure }\left(\mathrm{cm} \mathrm{H}_{2} \mathrm{O}\right)\end{array}$ & 0.064 & 1.36 & $0.98-1.87$ \\
\hline
\end{tabular}

Note: $(n=323)$.

\section{DISCUSSION}

This study identified the independent risk factors for the prediction of $\mathrm{RBC}$ transfusion after cardiac surgery in 323 patients in a large tertiary university hospital in São Paulo, Brazil.

Upon patient admission to the ICU after cardiac surgeries, nurses' activities are multiple and comprise receiving verbal report from the operating room nurse and anesthesiologist, rapid patient assessment, monitoring, connecting drainage devices, collecting blood, preparing and administering IV medications/fluids. Also, nurses must perform nursing procedures, assist with medical procedures, manipulate chest and mediastinal tubes to ensure patency, document patient progress, enter and retrieve computer data, interact with the family, supervise the nursing team, transport the patient when needed, check and re-stock supplies, and keep the environment clean ${ }^{(10-11)}$. Given these multiple activities, knowledge of institutional risk factors for a serious complications - RBC transfusion - should direct nursing care.

In our patient sample, the incidence of postoperative $\mathrm{RBC}$ transfusion was $6.2 \%$, of which most patients received one or two units of RBCs (95\%). Recent studies found a prevalence of 24.7 to $54.2 \%$ of patients receiving RBCs after cardiac surgery ${ }^{(2-3,6,6,17-22)}$.

This difference can be associated with the current lack of evidence for transfusion triggers after cardiac surgery ${ }^{(22)}$, leaving postoperative transfusion at the intensivist's discretion. Transfusion triggers vary from Hct $<23 \%$ to Hct $<30 \%(6,17-19)$. The first randomized clinical trial to compare a liberal with a restrictive $\mathrm{RBC}$ transfusion strategy in patients undergoing cardiac surgery suggested that transfusion targeting a Hct of $24 \%$ is as safe as targeting a Hct of $30 \%$, with respect to a composite end point of 30-day mortality and inpatient clinical complications ${ }^{(6)}$. Therefore, triggers are expected to become increasingly restrictive worldwide.

A recent study performed in a cardiac surgical ICU and a surgical ICU in the USA highlighted the need for nursing education in order to improve adherence to evidence-based transfusion practices. A low level of bedside nurse knowledge regarding $\mathrm{RBC}$ transfusion thresholds was found (only $8 \%$ of the nurses in the cardiac surgical ICU and $42 \%$ of nurses in the surgical ICU were aware of an ideal pretransfusion $\mathrm{Hb}$ threshold of $<7 \mathrm{~g} / \mathrm{dL})^{(23)}$. It should be noted that effective implementation of transfusion thresholds relies on knowledge and participation of all health care professionals caring for the patient, especially in institutions in which the professionals have interdisciplinary bedside rounds for case discussion. Compliance with evidence-based RBC transfusion threshold should prevent unnecessary transfusions and their acute and long-term complications, such as transfusion-related acute lung injury and cardiac morbidity.

Some of the actions that comprise an approach to minimize allogeneic blood transfusion in cardiac surgery include diagnosing and treating anemia and thrombocytopenia, suspending anticoagulants and antiplatelet agents, and selective laboratory evaluation ${ }^{(7)}$. All these actions count on systematic nursing activities. Awareness of important risk factors for 
$\mathrm{RBC}$ transfusion differentiates a knowledgeable, critical professional action from that of a simplistic, technical attitude.

Older age and a longer anesthetic duration were associated with postoperative RBC transfusion in our study. Other authors found these factors to be independent predictors of RBC transfusion ${ }^{(2-3,19-20,22)}$. A greater number of comorbidities - such as hypertension, diabetes mellitus, peripheral vascular disease, heart failure, chronic obstructive pulmonary disease - also contribute to an increased surgical complexity and longer duration of the procedure ${ }^{(17-20,24)}$. Because the clinical history has an impact on surgical complexity, duration and the requirement for blood transfusion, assessment for comorbidities should be accurately performed and documented by nurses preoperatively.

We believe that older age and surgical complexity could have also contributed to the need for higher positive endexpiratory pressures during mechanical ventilation in the ICU, used to improve pulmonary compliance and oxygenation after $\mathrm{CABG}^{(25)}$. RBC transfusion was also associated with higher postoperative heart rates after admission to the ICU, which is a sign of hemodynamic instability.

A lower weight was associated with postoperative RBC transfusion in ours and other studies ${ }^{(2-3,17-20,22)}$. In addition, weighing $<66.5 \mathrm{Kg}$ remained as an independent predictor for RBC transfusion in our multiple analyses. Patients with a lower weight suffer a more dramatic hemodilution during $\mathrm{CPB}$, which includes a dilution of both the coagulation factors and a decrease in the $\mathrm{Hct}^{(26)}$. Also, overweight and obese patients might have more adequate inflammatory and immune responses during $\mathrm{CPB}$ due to a sufficient nutritional reserve and a more efficient metabolic state ${ }^{(25)}$. Lower preoperative $\mathrm{Hb}$ levels, a factor associated with $\mathrm{RBC}$ transfusion in the current and previous studies ${ }^{(2,6,17-21)}$ would contribute to a greater decrease in Hct during CPB.

Also, a greater prevalence of intraoperative RBC transfusion was associated with the postoperative requirement for blood transfusion in our sample. Older age and lower preoperative Hct increase the likelihood of intraoperative RBC transfusion. On the other hand, overweight and obese patients have a decreased risk for intraoperative blood transfusion ${ }^{(27-28)}$. Therefore, in our sample, a lower weight might have contributed to increased risk of intraoperative and postoperative RBC blood transfusion.

One of the preoperative components that comprise optimization of the erythrocyte mass in order to minimize blood transfusion is early nutrition, with protein supplementation to support erythropoiesis ${ }^{(7)}$. Nursing caring for patients preoperatively must ensure accurate anthropometric assessment and documentation, and they must have the opportunity to intervene and optimize nutrition.

During $\mathrm{CPB}$, hypothermia is induced in order to prevent ischemia. However, it inhibits the activity of coagulation enzymes, depresses platelet function, and stimulates fibrinolysis ${ }^{(29)}$. Therefore, a lower preoperative platelet count with function impaired by $\mathrm{CPB}$ would contribute to excessive bleeding and the requirement for RBC transfusion. Actively warming hypothermic patients and cooling febrile patients in the postoperative period are also actions proposed to minimize blood transfusion in cardiac surgery ${ }^{(7)}$.
Because the CPB circuit is heparinized, heparin reversal with protamine is required intraoperatively. Nevertheless, microvascular bleeding can persist after reversal ${ }^{(30)}$. That is a possible reason for the association between a lower intraoperative volume of protamine and postoperative RBC transfusion.

Although our sample was intended to depict real world conditions, the inclusion of more complex surgeries such as cardiac transplantation and aortic corrections might have introduced a bias, as the nature of the surgery might lead the surgeon to more carefully revise the hemostatic technique. This is a possible reason for the absence of patients requiring cardiac transplantation and aortic corrections in the no $\mathrm{RBC}$ group.

Identification of patients at risk for RBC transfusion provides an opportunity to implement early treatment bundles in the postoperative ICU after cardiac surgery. Because our sample was most frequently transfused with RBCs due to surgical technical reasons, patients would benefit from surveillance prevention bundles in the operating room. Process improvements to minimize blood use and requirements for re-exploration have been suggested in the literature ${ }^{(31)}$.

Our study has some limitations. Data collected from patients' charts might be inaccurate, and our findings cannot be generalized because it was a single-center study. The surgeons who performed a very small number of surgeries may have introduced a bias. We also did not discriminate between those patients who received one or more units of $\mathrm{RBC}$, and we did not have information regarding patient severity, except for the NYHA functional classification. Other variables that were not identified in the review as predictors of $\mathrm{RBC}$ transfusion might be of clinical interest in this field, such as drainage volume through chest tubes and the number of valves repaired. Therefore, multicentric studies with a greater number of patients, standardized triggers for RBC transfusion, and information on the surgeons' experience, are required to increase the sensitivity, specificity and accuracy of prediction models.

\section{CONCLUSION}

The univariate factors associated with postoperative $\mathrm{RBC}$ transfusion included: older age; lower weight and height; lower preoperative platelet count; lower preoperative $\mathrm{Hb}$ levels; greater prevalence of preoperative platelet count $<150 \times 10^{3} / \mathrm{mm}^{3}$; a lower volume of intraoperative protamine; a longer duration of anesthesia; a greater prevalence of intraoperative $\mathrm{RBC}$ transfusion; a lower postoperative body temperature; a higher heart rate; and a higher positive end expiratory pressure during mechanical ventilation. The independent predictor of RBC transfusion was weight $<66.5 \mathrm{Kg}$, with a sensitivity of $65.0 \%$, a specificity of $68.0 \%$ and an accuracy of $66.0 \%$. Awareness of these factors can aid nurses to prioritize vigilance against excessive postoperative bleeding, support the implementation of transfusion thresholds as an institutional policy along with intraoperative and postoperative preventative bundles, differentiate critical professional actions from simplistic technical attitudes in direct patient care, assessment and pre - and postoperative documentation. 


\section{RESUMO}

Objetivo: Identificar preditores de transfusão de concentrado de hemácias (TCH) após cirurgia cardíaca. Método: Estudo de coorte prospectivo realizado com 323 adultos após cirurgia cardíaca de abril a dezembro de 2013. Um instrumento de coleta de dados foi construído pelas pesquisadoras contendo fatores associados a sangramento excessivo após cirurgia cardíaca encontrados na literatura, para investigação no pós-operatório imediato. A relação entre os fatores de risco e o desfecho foi verificada por análise univariada e regressão logística. Resultados: Os fatores associados à transfusão de concentrado de hemácias no pós-operatório imediato incluíram menor peso e altura, menor contagem plaquetária, menor nível de hemoglobina, maior prevalência de contagem plaquetária $<150 \mathrm{x} 10^{3} / \mathrm{mm}^{3}, \mathrm{menor}$ volume de protamina, maior duração da anestesia, maior prevalência de transfusão de concentrado de hemácias intraoperatória, menor temperatura corporal, maior frequência cardíaca e maior pressão positiva expiratória final. $\mathrm{O}$ preditor independente foi peso $<66,5 \mathrm{Kg}$. Conclusão: Encontraram-se fatores associados à transfusão de concentrado de hemácias no pós-operatório imediato de cirurgia cardíaca. O preditor independente foi o peso.

\section{DESCRITORES}

Cirurgia Torácica; Hemorragia; Transfusão de Sangue; Transfusão de Eritrócitos; Enfermagem Cardiovascular.

\section{RESUMEN}

Objetivo: Identificar predictivos de transfusión de concentrado de hematíes (TCH) después de cirugía cardiaca. Método: Estudio de cohorte prospectivo llevado a cabo con 323 adultos luego de cirugía cardiaca de abril a diciembre de 2013. Un instrumento de recolección de datos fue diseñado por las investigadoras abarcando factores asociados con sangrado excesivo tras cirugía cardiaca encontrados en la literatura, para la investigación en el posoperatorio inmediato. La relación entre los factores de riesgo y el resultado fue verificada por análisis univariado y regresión logística. Resultados: Los factores asociados con la transfusión de concentrado de hematíes en el posoperatorio inmediato incluyeron peso y altura, menor conteo plaquetario, menor nivel de hemoglobina, mayor prevalencia de conteo plaquetario $<150 \times 10^{3} / \mathrm{mm}^{3}$, menor volumen de protamina, mayor duración de la anestesia, mayor prevalencia de transfusión de concentrado de hematíes intraoperatorio, menor temperatura corporal, mayor frecuencia cardiaca y mayor presión positiva espiratoria final. El predictor independiente fue peso $<66,5 \mathrm{~kg}$. Conclusión: Se hallaron factores asociados con la transfusión de concentrado de hematíes en el posoperatorio inmediato de cirugía cardiaca. El predictor independiente fue el peso.

\section{DESCRIPTORES}

Cirugía Torácica; Hemorragia; Transfusión Sanguínea; Transfusión de Eritrocitos; Enfermería Cardiovascular.

\section{REFERENCES}

1. Mohnle P, Snyder-Ramos SA, Miao Y, Kulier A, Böttiger BW, Levin J, et al. Postoperative red blood cell transfusion and morbid outcome in uncomplicated cardiac surgery patients. Intensive Care Med. 2011;37(1):97-109.

2. Stone GW, Clayton TC, Mehran R, Dangas G, Parise H, Fahy M, et al. Impact of major bleeding and blood transfusions after cardiac surgery: analysis from the Acute Catheterization and Urgent Intervention Triage strategY (ACUITY) trial. Am Heart J. $2012 ; 163(3): 522-9$.

3. Bhaskar B, Dulhunty J, Mullany DV, Fraser JF. Impact of blood product transfusion on short and long-term survival after cardiac surgery: more evidence. Ann Thorac Surg. 2012;94(2):460-7.

4. Horvath KA, Acker MA, Chang H, Bagiella E, Smith PK, Iribarne A, et al. Blood transfusion and infection after cardiac surgery. Ann Thorac Surg. 2013;95(6):2194-201.

5. Jakobsen C-J, Ryhammer PK, Tang M, Andreasen JJ, Mortensen PE. Transfusion of blood during cardiac surgery is associated with higher long-term mortality in low-risk patients. Eur J Cardiothorac Surg. 2012;42(1):114-20.

6. Hajjar LA, Vincent JL, Galas FR, Nakamura RE, Silva CM, Santos MH, et al. Transfusion requirements after cardiac surgery: the TRACS randomized controlled trial. JAMA. 2010;304(14):1559-67.

7. Santos AA, Silva JP, Silva LF, Sousa AG, Piotto RF, Baumgratz JF. Therapeutic options to minimize allogeneic blood transfusions and their adverse effects in cardiac surgery: a systematic review. Rev Bras Cir Cardiovasc. 2014;29(4):606-21.

8. Ravn HB, Lindskov C, Folkersen L, Hvas AM. Transfusion requirements in 811 patients during and after cardiac surgery: a prospective observational study. J Cardiothorac Vasc Anesth. 2011;25(1):36-41.

9. Lopes CT, Santos TR, Brunori EH, Moorhead SA, Lopes JL, Barros AL. Excessive bleeding predictors after cardiac surgery in adults: integrative review. J Clin Nurs. 2015 Aug 7. doi: 10.1111/jocn.12936. [Epub ahead of print]

10. Martin CG, Turkelson SL. Nursing care of the patient undergoing coronary artery bypass grafting. J Cardiovasc Nurs. 2006;21(2):109-17.

11. Abbey M, Chaboyer W, Mitchell M. Understanding the work of intensive care nurses: A time and motion study. Aust Crit Care. $2012 ; 25(1): 13-22$.

12. Lopes CT, Brunori EH, Santos VB, Moorhead SA, Lopes JL, Barros AL. Predictive factors for bleeding-related re-exploration after cardiac surgery: a prospective cohort study. Eur J Cardiovasc Nurs. 2015 Apr 17. [Epub ahead of print]

13. Chow S-C, Wang H, Shao J. Sample size calculations in clinical research. 2th ed. Basel: Chapman \& Hall/CRC; 2007.

14. Karlsson M, Ternström L, Hyllner M, Baghaei F, Nilsson S, Jeppsson A. Plasma fibrinogen level, bleeding, and transfusion after on-pump coronary artery bypass grafting surgery: a prospective observational study. Transfusion. 2008;48(10):2152-8.

15. Society of Thoracic Surgeons Blood Conservation Guideline Task Force; Ferraris VA, Ferraris SP, Saha SP, Hessel EA 2nd, Haan CK, Royston BD, et al. Perioperative blood transfusion and blood conservation in cardiac surgery: the Society of Thoracic Surgeons and The Society of Cardiovascular Anesthesiologists clinical practice guideline. Ann Thorac Surg. 2007;83(5 Suppl):S27-86.

16. Haneya A, Diez C, Kolat P, Suesskind-Schwendi MV, Ried M, Schmid C, et al. Re-exploration for bleeding or tamponade after cardiac surgery: impact of timing and indication on outcome. Thorac Cardiovasc Surg. 2015;63(1):51-7. 
17. Ranucci M, Castelvecchio S, Frigiola A, Scolletta S, Giomarelli P, Biagioli B. Predicting transfusions in cardiac surgery: the easier, the better: the transfusion risk and clinical knowledge score. Vox Sang. 2009;96(4):324-32.

18. Elmistekawy EM, Errett L, Fawzy HF. Predictors of packed red cell transfusion after isolated primary coronary artery bypass grafting--the experience of a single cardiac center: a prospective observational study. J Cardiothorac Surg. 2009;4:20.

19. Van Straten AH, Kats S, Bekker MW, Verstappen F, ter Woorst JF, van Zundert AJ, et al. Risk factors for red blood cell transfusion after coronary artery bypass graft surgery. J Cardiothorac Vasc Anesth. 2010;24(3):413-7.

20. Williams ML, Trivedi JR, Doughtie C, Slaughter MS. Is female sex an independent risk factor for perioperative transfusion in coronary artery bypass graft surgery? J Am Coll Surg. 2011;212(3):362-6.

21. Sá MP, Soares EF, Santos CA, Figueiredo OJ, Lima ROA, Rueda FG, et al. Predictors of transfusion of packed red blood cells in coronary artery bypass grafting surgery. Rev Bras Cir Cardiovasc. 2011;26(4):552-8.

22. Paone G, Brewer R, Theurer PF, Bell GF, Cogan CM, Prager RL; Michigan Society of Thoracic and Cardiovascular Surgeons. Preoperative predicted risk does not fully explain the association between red blood cell transfusion and mortality in coronary artery bypass grafting. J Thorac Cardiovasc Surg. 2012;143(1):178-85.

23. Murphy DJ, Pronovost PJ, Lehmann CU, Gurses AP, Whitman GJR, Needham DM, et al. Red blood cell transfusion practices in two surgical intensive care units: a mixed methods assessment of barriers to evidence-based practice. Transfusion. 2014;54(10 Pt 2):2658-67.

24. Hajjar LA, Fukushima JT, Almeida JP, Osawa EA, Galas FRBG. Strategies to reduce blood transfusion: a Latin-American perspective. Curr Opin Anaesthesiol. 2015;28(1):81-8.

25. Borges DL, Nina VJS, Costa MAG, Baldez TE, Santos NP, Lima IM, et al. Effects of different PEEP levels on respiratory mechanics and oxygenation after coronary artery bypass grafting. Rev Bras Cir Cardiovasc. 2013;28(3):380-5.

26. Alström U, Granath F, Friberg Ö, Ekbom A, Ståhle E. Risk factors for re-exploration due to bleeding after coronary artery bypass grafting. Scand Cardiovasc J. 2012;46(1):39-44.

27. Valentijn TM, Galal W, Tjeertes EK, Hoeks SE, Verhagen HJ, Stolker RJ. The obesity paradox in the surgical population. Surgeon. 2013;11(3):169-76.

28. Nolan HR, Davenport DL, Ramaiah C. BMI is an Independent Preoperative Predictor of Intraoperative Transfusion and Postoperative ChestTube Output. Int J Angiol. 2013;22(1):31-6.

29. Thiele RH, Raphael J. A 2014 update on coagulation management for cardiopulmonary bypass. Semin Cardiothorac Vasc Anesth. 2014;18(2):177-89.

30. Taneja R, Berry L, Pappu U, Stitt L, Sayal P, Allen P, et al. Protamine requirements in cardiac surgery: effect of changes in the heparin reference standard. J Cardiothorac Vasc Anesth. 2014;28(5):1227-32.

31. Vivacqua A, Koch CG, Yousuf AM, Nowicki ER, Houghtaling PL, Blackstone EH, et al. Morbidity of bleeding after cardiac surgery: is it blood transfusion, re-exploration for bleeding, or both? Ann Thorac Surg. 2011;91(6):1780-90. 